\title{
Eco-hotels as an example of environmental responsibility and innovation in savings in the hotel industry
}

\author{
Marija Kostić $^{1 *}$, Milica Ratković ${ }^{2}$ Fabio Forlani ${ }^{3}$ \\ ${ }^{1}$ University of Kragujevac, Faculty of Hotel Management and Tourism in Vrnjačka Banja, \\ Serbia \\ 2 PhD student, University of Kragujevac, Faculty of Hotel Management and Tourism in \\ Vrnjačka Banja, Serbia \\ ${ }^{3}$ University of Perugia, Faculty of Economics, Italy
}

\begin{abstract}
Green hotels are ecological buildings whose managers set up programs to save water and energy, and reduce solid waste, thereby saving money and aiding preservation of the environment. These hotels have guidelines so that the guests can stay in a safe, non-toxic and energy-efficient lodging. Green hotels are introducing environmental standards and use elements of environmentally friendly new technologies, thereby making a significant contribution to the protection of the environment and achieving better operational results. Looking at global trends in green tourism and hospitality, caused by turbulent development and carrying many negative consequences, the purpose of this paper is to point out and affirm the advantages provided by the green hotels. It also suggests that Serbia can become a more competitive destination considering its potential and resources.
\end{abstract}

Keywords: green hotels, savings, innovations, hospitality

JEL classification: Z320

\section{Eko hoteli kao primer inovativnosti ekološke odgovornosti i uštede u hotelskoj industriji}

Sažetak: Eko hoteli su ekološke zgrade čiji menadžeri nastoje da sprovedu različite programe za uštedu vode, energije i otpada, čime se štedi novac i pomaže očuvanje životne sredine. Ovi hoteli imaju tačno određene smernice za zaštitu životne sredine, tako da gosti mogu ostati na bezbednom, netoksičnom i energetski efikasnom smeštaju. Zeleni hoteli uvode ekološke standarde i koriste elemente ekološki prihvatljivih novih tehnologija, čime značajno doprinose zaštiti životne sredine i postižu bolje rezultate poslovanja. Posmatrajući globalne trendove u zelenom hotelijerstvu i ekoturizmu izazvane turbulentnim razvojem koji sa sobom nosi brojne negativne posledice, svrha ovog istraživanja je da istakne prednosti koje obezbeđuju zeleni hoteli i značaj njihove primene, kako bi Srbija mogla postati konkuretna destinacija uzimajući u obzir svoje izvore i potencijale.

Ključne reči: zeleni hoteli, uštede, inovacije, hotelijerstvo JEL klasifikacija: Z320

* marija.kostic@kg.ac.rs 


\section{Introduction}

Escaping the mass-produced uniform travel experience, eco-friendly practices are becoming greatly appreciated by conscious tourists who are seeking more authentic and unique tourist experiences (Leal Londoño \& Hernandez-Maskivker, 2016). Environmental management of businesses in the tourism industry has grown consistently over the past 20 years, with efforts to identify the most important drivers, the potential benefits, and the degree of implementation" (Molina-Azorín, 2009). Governments do not adequately regulate the tourism or hospitality industry by law, so a large number of voluntary or self-regulatory tools are being implemented for sustainable tourism, such as best environmental practices, environmental management systems, eco-labels and certifications, environmental performance indicators and codes of conduct (Ayuso, 2007; Chou et al., 2012). The hotels of the future will be defined by new needs of people and new travel motivations. These in turn will be defined by some new conditions of work and life of people in the new economic, social and political environment. New techniques and technologies of communication will reduce the volume of business trips, whereas travels for leisure, entertainment and studying will be much more frequent. The hotel industry market will be more segmented because the guests will increasingly look for different contents. The service industry has to take responsibility for contributing to environmental degradation and the problems arising from climate change, particularly as the hospitality industry continues to gain importance (Kasim, 2009).

Nowadays, the hotels have realized that they cannot sustain their company's life without having environmental sensitivity (Dincer et al., 2017). Every step in the production, modification and use of energy interacts with the environment, changing the Earth and its inhabitants. The interaction of the energy with the Earth and its ecological systems, categorized in terms of different energy produced operations, extremely damages the natural environment (Tester et al., 2012).

Urbanization, growing daily worldwide, will surely be accompanied by high consumption and the loss of natural resources. The calculations already show that if developing countries urbanize and consume resources as developed countries have already done, the environmental resource base should be as big as four Earths to meet their growth. But, of course, we only have one Earth and we must take care of its preservation (Suzuki et al., 2010).

The rapid development of tourism has led to significant degradation of natural and anthropogenic attractiveness, notably to uncontroled uses of natural resources, which are limited, and many of them non-renewable. For this reason, it was necessary to find a solution for the controlled development of tourism. The solution was found in the development of sustainable tourism (Kostić et al., 2016). Sustainable tourism development is an imperative that arises in modern conditions (Krstić et al., 2015; Munitlak-Ivanović et al., 2017). Through sustainable tourism, it is possible to work toward the aim of "meeting the needs and aspirations of today without compromising the ability of future generations to meet their own needs" (Brudtlland, 1989). Ecological values, ecological awareness and ecological culture are important determinants of sustainable development (Stanković, 2018).

This study focuses on presenting the ways of using renewable energy sources in the hotels, in order to adapt to the current megatrends, as it is shown in the examples of eco-hotels worldwide, as well as in Italy and Serbia. This can be considered an innovation in the field of savings in the hotel industry and environmental protection. "Hotels are striving to establish the image of a green hotel because it is the latest tourism trend, and are thus better filled than conventional hotels” (Blagojević, 2002). This trend towards green hotels does not not only address environmental concerns by saving energy, water, and resources, but is also expected 
to improve guest satisfaction and comfort (Millar \& Baloglu, 2008; Becker, 2009). Green management along with green marketing has been recognized as one of the most important business strategies to achieve responsible, sustainable and accessible tourism (Gavrilović \& Maksimović, 2018).

The main aim of this research is to highlight both the importance of assuming greater ecological responsibility in the hotel industry and the fact that hotels should operate following the principles of sustainable development. It is worth mentioning that a research conducted in 2007 showed that that $75 \%$ of the guests are willing to participate in an ecological initiative of the hotel they are staying in, while the following study showed that $65 \%$ of the guests thought that the good green management helped the image and competitiveness of the hotel (Penny, 2007). In addition, the goal of the work is to analyze the use of renewable energy sources and ecological practices in the hotels located in Vrnjačka Banja spa and its surrounding areas.

The results of the survey research are about renewable energy sources and respect for ecological principles in these hotels. Also, it shows the satisfaction of the customers who are interested in staying in hotels that respect ecological principles.

\section{Analysis of the survey research}

\subsection{Survey research on the ecological responsibility of the hotels in Vrnjačka Banja}

For the purposes of this study, a survey was conducted to determine the level of ecological responsibility of the hotels in Vrnjačka Banja and its surroundings. The method that was used was the closed questionnaire, consisting of a set of questions divided into 6 groups. The first group of questions was related to the basic information about the hotels: their names, categorization, location and capacity. The second part of the questionnaire contained questions concerning the environmental practices that are used in the hotels. Here, we primarily analyzed the recycling, the use of energy with saving light bulbs and sensor lights, the use of organic foods etc. The third part of the questionnaire related to the specific examples of environmental activities carried out in the hotels' accommodation units. The fourth part of the questionnaire contained questions relating to renewable energy sources which the hotels apply - the solar and geothermal energy use, the disposal of compost, the wind turbines, etc. The fifth part of the questionnaire focused on waste management. The sixth part of the questionnaire addressed how much the hotels respect ecological principles.

The survey was conducted on a selected sample and was distributed to ten hotels in Vrnjačka Banja and its surrounding towns. The questionnaire was filled out by the hoteliers. The data collection was conducted in March 2017.

\subsubsection{Results of the research}

The study included ten hotels in Vrnjačka Banja, Kraljevo and Čačak: the "Solaris Resort", the "Aleksandar", the "Garni Hotel Kralj", the "Merkur Specialized Hospital", the "Promenada Resort", the "Breza", the "Tourist", the "Tehnograd|, the "Beograd" and the "Kablar Wellness Center”. The analysis of the hotels' categorization showed that the highest percentage was the three-star hotels, with a share of $50 \%$, while $40 \%$ of the included hotels had four-stars and two-star hotels made for only $10 \%$. The hotels with one and five stars were not represented in the survey.

When talking about the capacity of the hotels, the largest share in the study were smaller hotels with a capacity of up to fifty units, with a share of $50 \%$. The hotels with a capacity of fifty to one hundred units had a share of $30 \%$, while the hotels with a capacity of one hundred to three 
hundred units, as well as the hotels of three hundred to one thousand units, both had a share of $10 \%$.

In the second part of the questionnaire, the environmental practices applied in the hotels were analyzed. For the question about the methods that hotels used in their businesses, we got the results revealing that the most prominent was the use of LEED light bul0062s in public areas with a share of $90 \%$ of the surveyed hotels. As much as $50 \%$ of the hotels used sensor lights in the hallways, $40 \%$ recycled paper, $30 \%$ recycled bottles and cans, 30\% purchased organic food, while the reuse of the plastic bags was being applied by only $10 \%$ of them. This relation is shown in Figure number 1.

Figure 1: Ecological practices used in hotel

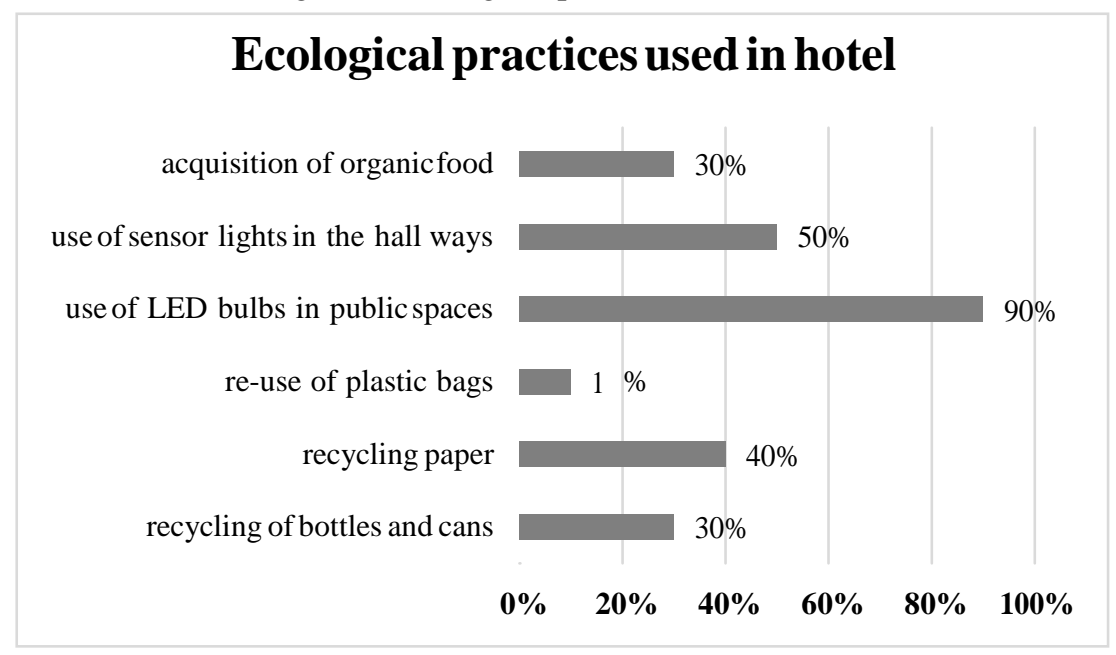

Source: Authors' research

When it comes to the environmental activities that were used in the accommodation units, the use of energy-saving light bulbs in a bedroom (80\% of the hotels) and a bathroom (70\% of the hotels) was very dominant. The soap and shampoo dispensers were used in $50 \%$ of the hotels. The toilets with a controled flow of water were used in $50 \%$ of the hotels, the tap water with a controled flow in $40 \%$, and the showers with a controlled flow in $30 \%$ of the hotels. The key cards that are used to activate the electricity in the accommodation units were present in $40 \%$ of the surveyed hotels. The recycling bins were used in $20 \%$ of the hotels. The reuse of towels was present in only $10 \%$ of the establishements, while other hotels changed towels daily. Motion sensors in the rooms and the change of bed linen upon request were not applied in any of the hotels. This relation is shown in Figure number 2. 
Figure 2: Ecological activities implemented in the accommodation units

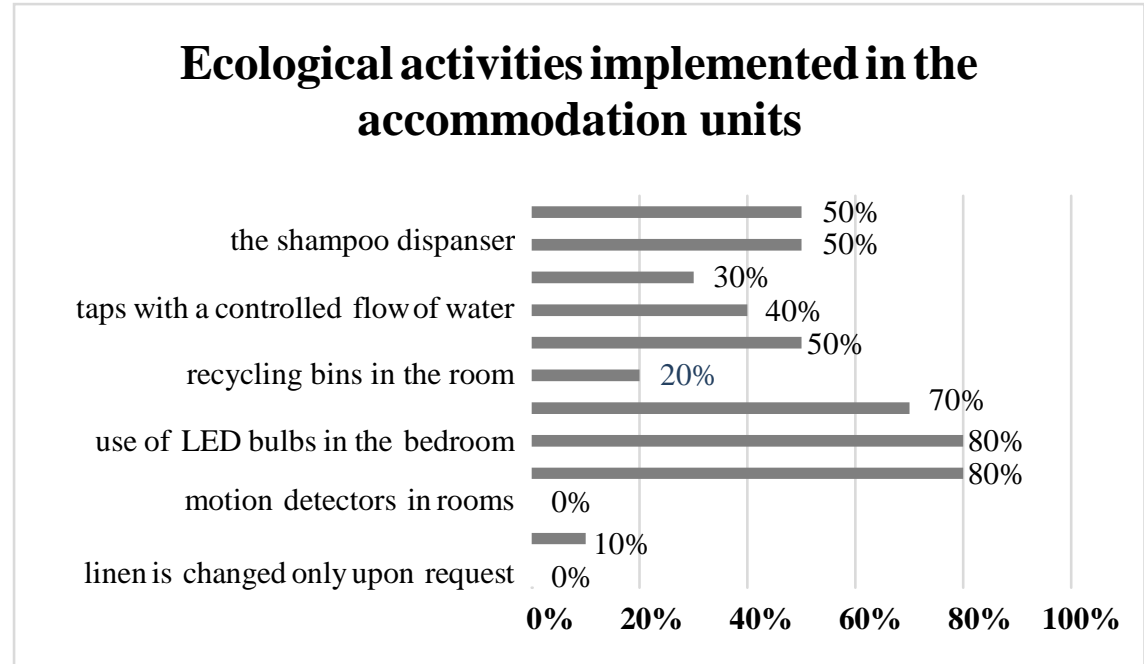

Source: Authors' research

The fourth part of the questionnaire was related to the use of renewable energy sources. Most applicable renewable energy sources that were used were the solar panels with a share of $30 \%$. The geothermal energy use (the use of thermal mineral water sources) was applied in only two hotels - 20\%. The disposal of compost as the organic fertilizer was applied in $10 \%$ of the hotels, while the wind turbines were not applied in any of the hotels. This relation is shown in Figure 3.

Figure 3: Renewable energy sources

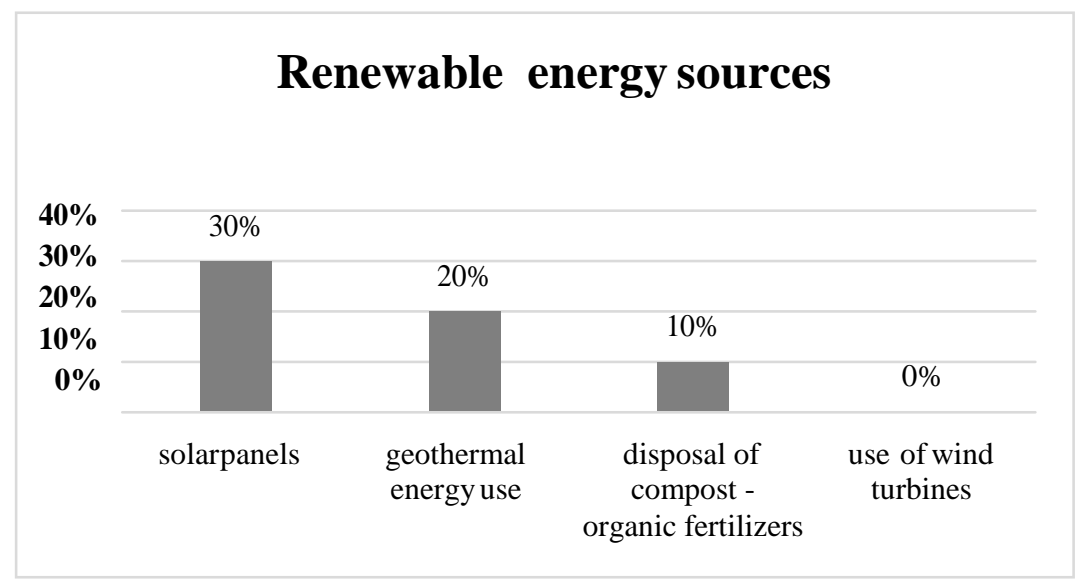

Source: Authors’ research

When it comes to waste management, the research showed that the hotels did not apply proper disposal. Safe disposal of oil was applied in $70 \%$ of the hotels, while the reuse of water and the use of waste materials as an energy source were not applied at all.

Attitudes of the hoteliers on how much their hotel respected the ecological principles in their operations, were measured by the Likert scale ranging from 1 to 5 , with 1 representing the minimal respect for ecological principles, and 5 indicating that the respect for ecological 
Kostić, M. et al. - Eco-hotels as an example of environmental responsibility and innovation in savings in the hotel industry -

Hotel and Tourism Management, 2019, Vol. 7, No. 2: 47-56.

principles is at the maximum level. The hoteliers gave an average review score of 3.2 , which indicates that the observed ecological principles were moderately respected in the surveyed hotels.

\subsubsection{Discussion}

Considering the results, it can be concluded that the environmental responsibility of the hotels in Vrnjačka Banja and its surrounding towns is not on a high level, although the hotels have plenty of resources and the potentials for application of ecological principles. Also based on the research survey results, the responses to the initial research questions would as follows.

Regarding the first research question, What environmental practices do hotels usually apply?, the majority of respondents answered that their hotel mainly used energy-saving bulbs and sensor lighting in hallways, while a small number of hotels recycled paper, bottles and cans. Also, a small number of hotels purchased organic food. These data are disturbing because recycling is an ordinary, frequent activity in many countries. However, it is obviously rarely present in Serbia.

The second research question was Which of the environmental activities have been implemented in the accommodation units?. This segment is also dominated by the use of energy-saving light bulbs, the dispensers for soap and shampoo, while the controled flow of water in bathrooms and the key cards used to activate the electricity in the rooms are rarely represented. Recycling is rarely applied, and the bed linen is not changed only upon request. The towels are changed every day. Based on these results, the conclusion one can come to is that the hotels almost never pay attention to environmental protection, which could contribute to the reduction in business costs. The hotels should look up to the hotels worldwide as role models. They can also find role models in the examples of eminent hotels in Serbia which respect ecological principles that have an effect on the cost control in their operations. The "Izvor" hotel in Aranđelovac, for example, uses green cards, which engages guests in environmental protection. If the guests leaves the green card on their bed, it means that it is not necessary to change the sheets. This affects the protection of the environment and the savings in the hotel business.

As for the question What renewable sources of energy do hotels apply?, the research showed that the hotels did not apply renewable energy to a great extent. The solar panels are the most common, while two hotels use thermal mineral water springs. The wind turbines are not represented anywhere, while the disposal of the compost is applied in only one hotel. Although the construction of a system of renewable energy is very expensive, after a certain period of time, the investment is more than worth it. It pays off, from both economic and sustainable development aspects. The "Merkur Specialized Hospital" in Vrnjačka Banja and the "Kablar Wellness Center" in Ovčar Banja are the only hotels that are taking advantage of the benefits offered by the location of their spas, by using thermal mineral water in their wellness centers.

The fourth question was Does the hotel management manage waste disposal adequately?. The research showed that these hotels did not apply proper disposal of waste. The only applied measure was the safe disposal of oil.

Regarding the question How much does the hotel respect environmental principles?, we got an average of 3.2/5, which should be taken for a fact, since most respondents were not sufficiently informed about the possibilities of the development of green management in the hotel industry. 


\subsection{Survey research on the guests' satisfaction}

The following research represents the relationship between the application of ecological practices in the hotels, the guests' satisfaction and their willingness to recommend it.

The research is based on a structured questionnaire. The questionnaire consists of two groups of direct questions, with a total of seven claims, which are evaluated on the Likert scale, from 1 to 5 , where number 1 marks an absolute dissatisfaction, while the answer marked by number 5 indicates the absolute satisfaction of the respondents.

The survey was conducted on a selected sample and filled out by the hotel guests in Vrnjačka Banja and its neighboring areas. The data collection was conducted in June 2017.

\subsubsection{Results of the research}

The first group of questions was related to the personal characteristics of the respondents - the gender, age and education. The second part of the questionnaire contained questions relating to the guests' satisfaction with the ecological aspects that were used in the hotel.

The analysis of the gender of the respondents showed that there were more female (56.47\%) than male $(43.53 \%)$ participants. The highest percentage of the respondents were those aged between 25 and 35 (42.35\%). People under 25 years of age make for $28.23 \%$ and people aged $35-45$ are represented with $21.17 \%$.

As regards the education level of the respondents, the majority of the respondents have a Bachelor's degree (69.41\%) and a Master's degree (22.35\%).

The second part of the questionnaire contained questions relating to the guests' satisfaction with the ecological aspects used in the hotel. The respondents gave the highest rating to the guests' willingness to recommend a green hotel (4.70\%), while the lowest rating was given to the readiness to pay higher accommodation prices in a green hotel $(2.86 \%)$. The results of other individual claims were the following: the hotel should operate in accordance with environmental protection (4.96\%), the guests show the intention to stay in the green hotel which uses renewable energy sources (3.98\%), and the guests would give positive recommendation of the hotel (4.70\%). This relation is shown in Figure number 4 .

Figure 4: Respondents satisfaction with the green aspects of the hotel

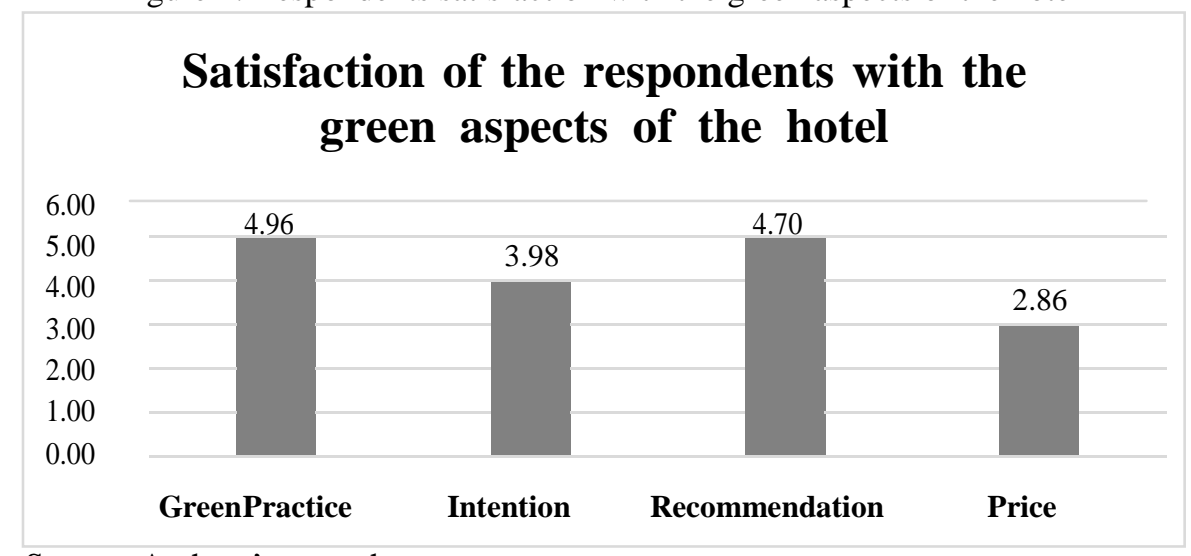

Source: Authors' research 


\subsubsection{Discussion}

The results of this research have shown that the application of green business practices in the hotel industry, which is in accordance with the principles of environmental protection, positively affects the satisfaction of the guests, their intention to stay in the green hotel as well as their willingness to recommend it to their friends. However, the consumers are not ready to pay a higher price for this service in the hotel. On the other hand, green hotels' savings in water, energy and solid waste reduction can significantly reduce their operating costs, so the application of green business practices has a double positive impact. Primarily, there is the satisfaction of consumers and their loyalty, but also the reduction of the cost of their business, which allows lower prices of services in these hotels. The green hotel brand is a powerful way of attracting new guests and building their loyalty.

In terms of environmental pollution, more and more tourists insist on products and services that are not harmful to the environment, and in accordance with the principles of conservation of the environment. In this context, "green hotels" are becoming a significant segment of the hotel industry. They help protect the environment, but also reduce operating costs ( $\underline{\text { Sekulić et }}$ al., 2014).

Green hotels are becoming an increasingly important segment of the hotel industry in the world, while the construction of these is very rare in Serbia. Based on the application of green standards in business, Serbian hotels could quickly and easily differentiate from domestic competition. The care for the environment and the future generations positively influences the attitude of the guests towards these hotels and can yield better business results.

\section{Conclusion}

In view of the importance it has acquired, the tourism sector has faced continuous changes in the industry, the manner in which it is observed by clients and the environment in general, which increases the need to respond to the social demands and responsibilities of the environment in which it operates in (Fernández-Robin et al., 2019). In recent years, environmental protection has become extremely important for both the company and the society, while the importance of the implementation of standards of environmental management grows constantly. There are different forms of environmental pollution. There is also the pressure of public opinion, which leads to the changes in general awareness of the public and reveals the need for technological and organizational measures that should be taken. There is a tendency of growth of new consumers who are willing to pay more for the services of companies that do socially responsible businesses. Today, the environmental component of their products is highly desirable and demanded in the market. This indicates a growing number of modern eco-hotels or green hotels.

The principle of green politics is not just about planting a tree in front of a hotel. It is about the existence of such a hotel that operates according to the principles of green hospitality. This primarily refers to savings in water and energy, being environmentally friendly and implementing waste management systems, recycling, using non-toxic cleaning products and paint, and implementing other procedures that comply with green policies.

The initial step towards achieving sustainability of a hotel starts from the property. It must comply with certain measures to reduce environmental impact and, above all, increase energy efficiency. It is necessary to provide the most energy-efficient ratio of surface area of the building in relation to the climate, the environment and the purpose. It should emphasize the use of natural light, insulation and natural ventilation. The use of local materials, which 
require minimal transport and are not harmful to the environment, is recommended, as well as recycled materials or those that can be recycled or reused later (Maksin et al., 2011).

The primary goal of the introduction of green management in hospitality in Serbia is preserving the environment and natural tourism resources. Those are very important elements of the tourist offer, and they represent a compatible part of the Serbian offer on the market.

The implementation of business rules related to the green hotel management companies in Serbia could improve the quality of accommodation facilities. The employees and the residents need to be more educated in terms of environmental protection, which would certainly bring better business results.

In the years to come, only sustainable hospitality management, which is economically viable, socially acceptable and safe for the environment, will succeed. Serbia is at the beginning of the introduction of eco-standards, and it is necessary to create the environment for improving the hotel industry through favorable legislation. This implies better regulation of the categorization of the hotels, which will force hotels in Serbia to provide a higher level of service following with the principles of green hospitality.

At the time of this study, the number of green hotels in Serbia, especially in Vrnjačka Banja, was quite small. Yet, some results of this study should be considered as a starting point for the future hotel strategies and development since the preservation of nature and natural resources are the most important elements of the tourist offer in Vrnjačka Banja. To address the challenges faced in this research, future research could involve expanding the study to include additional case studies as new green hotels have been developed.

\section{References}

1. Ayuso, S. (2007). Comparing voluntary policy instruments for sustainable tourism: the experience of the Spanish hotel sector. Journal of Sustainable Tourism, 15(2), 144-159. https://doi.org/10.2167/jost617.0

2. Becker, E. J. (2009). The Proximity Hotel: A Case Study on Guest Satisfaction of Sustainable Luxury Environments, Master's Thesis, The University of North Carolina at Greensboro, Greensboro, NC.

3. Blagojević, S. (2002). Ekološki trendovi u savremenom turizmu [Ecological trends in contemporary tourism]. Turizam, 6, 39-40.

4. Brundtland, G. H. (1989). Protecting the Global Commons, Earth Ethics.

5. Chou, C. J., Chen, K. S., \& Wang, Y. Y. (2012). Green practices in the restaurant industry from an innovation adoption perspective: Evidence from Taiwan. International $\begin{array}{llll}\text { Journal of } & \text { Hospitality }\end{array}$ https://doi.org/10.1016/j.ijhm.2011.09.006

6. Dincer, F. I., Akova, O., Ertugral, M. S., \& Cifci, M. A. (2017). Green innovation practices in hotel enterprises. Eurasian Social Sciences Journal, 1, 58-73.

7. Fernández-Robin, C., Celemín-Pedroche, M. S., Santander-Astorga, P., \& AlonsoAlmeida, M. M. (2019). Green practices in hospitality: A contingency approach. Sustainability, 11, 3737. https://doi.org/10.3390/su11133737

8. Gavrilović, Z., \& Maksimović, M. (2018). Green innovations in the tourism sector. Strategic Management, 23(1), 36-42. https://doi.org/10.5937/StraMan1801036G

9. Kasim, A. (2009). Managerial attitudes towards environmental management among small and medium hotels in Kuala Lumpur. Journal of Sustainable Tourism, 17(6), 709725. https://doi.org/10.1080/09669580902928468

10. Kostić, M., Milićević, S., \& Vulićević, I. (2016). Mogućnost razvoja ekoturizma u Srbiji [Possibility of ecotourism development in Serbia]. Ecologica, 22(81), 131-136. 
11. Krstić, B., Petrović, J., \& Stanišić, T. (2015). Analysis of key indicators of economic dimensions of spas' sustainable development in Serbia as tourism destinations. Ekonomika, 61(3), 61-71. https://doi.org/10.5937/ekonomika1503061K

12. Leal Londoño, M. P., \& Hernandez-Maskivker, G. (2016). Green practices in hotels: the case of the GreenLeaders Program from TripAdvisor. WIT Transactions on Ecology and the Environment, 201, 1-13. https://doi.org/10.2495/ST160011

13. Maksin, M., Pucar, M., Milijić, S., \& Korać, M. (2011). Održivi razvoj turizma u Evropskoj uniji i Srbiji [Sustainable tourism development in the European Union and Serbia]. Beograd: Institut za arhitekturu i urbanizam Srbije.

14. Millar, M., \& Baloglu, S. (2008). Hotel guests' preferences for green hotel attributes. Hospitality Management, Paper 5.

15. Molina-Azorin, J. F. (2009). Understanding how mixed methods research is undertaken within a specific research community: The case of business studies. International $\begin{array}{llll}\text { Journal of Multiple Research Approaches, 3(1), } & \text { 47-57. }\end{array}$ https://doi.org/10.5172/mra.455.3.1.47

16. Munitlak-Ivanović, O., Zubović, J., \& Mitić, P. (2017). Relationship between sustainable development and green economy: Emphasis on green finance and banking. Economics of Agriculture, 64(4), 1467-1482. https://doi.org/10.5937/ekoPolj1704467M

17. Penny, W. Y. K. (2007). The use of environmental management as a facilities management tool in the Macao hotel sector. Facilities, 25(7/8), 286-295. https://doi.org/10.1108/02632770710753325

18. Sekulić, D., Mandarić, M., \& Maksimović, N. (2014). Uticaj poslovne zelene prakse na satisfakciju i lojalnost potrošača u hotelskoj industriji [The impact of green business practices on consumer satisfaction and loyalty in the hotel industry]. Ecologica, 21(74), 312-316.

19. Stanković, J. (2018). Green marketing and green product. Economics of Sustainable Development, 2(2), 37-46.

20. Suzuki, H., Dastaur, A., Moffatt, S., Yabuki, N., \& Maruyama, H. (2010). Eco² Cities Ecological Cities as Economic Cities. Washington DC: The World Bank.

21. Tester, J. W., Drake, E. M., Driscoll, M. J., Golay, M. W., \& Peters, W. A. (2012). Sustainable energy: choosing among options. Massachusetts: MIT Press.

Received: 13 November 2018; Sent for revision: 26 November 2018; Accepted: 9 December 2019 